\title{
Supporting more successful language learning: Approaches for helping post-secondary learners in three contexts
}

\author{
Elaine K. Horwitz a * (D), Lama Nassif b (D), Duygu Uslu-Ok c (D), Claire \\ Meadows-Parrish d
}

a The University of Texas at Austin, 1912 Speedway STOP D5700, Austin, TX 78712, United States

${ }^{b}$ Williams College, 85 Mission Park Drive, Williamstown, MA 01267, United States

${ }^{c}$ The University of Texas at Austin, 1912 Speedway STOP D5700, Austin, TX 78712, United States

${ }^{d}$ The University of Texas at Austin, 1912 Speedway STOP D5700, Austin, TX 78712, United States

Received 26 June 2017 | Received in revised form 6 August 2017 | Accepted 20 August 2017

\begin{abstract}
This paper offers a number of suggestions for foreign and second language teachers who want to help their students develop more positive learning characteristics. In response to a graduate-level methods class designed to help participants develop student-centered instruction, this paper presents three approaches for helping post-secondary language learners in three contexts: Syria, Turkey, and the U.S. The approaches involve learner training projects aimed at influencing learner beliefs and expectations (Project 1), reducing learner anxiety (Project 2), and encouraging motivation and learner autonomy (Project 3). The projects target beginning and intermediate-level English as a foreign language (EFL) and Spanish-language learners. They involve hands-on teaching strategies, awareness-raising activities, and integration of instructional technology. The paper presents a rationale for each project and includes sample activities. It ends with reflections on the learner training projects and implications for the development of such projects in different language learning contexts.
\end{abstract}

(C) 2017 EJAL \& the Authors. Published by Eurasian Journal of Applied Linguistics (EJAL). This is an open-access article distributed under the terms and conditions of the Creative Commons Attribution license (CC BY-NC-ND) (http://creativecommons.org/licenses/by-nc-nd/4.0/).

Keywords: Learner support; learner autonomy; learner beliefs; language anxiety; L2 motivation; teacher training

\section{Introduction}

In recent decades, the language teaching profession has increasingly emphasized the importance of supporting the development of learner autonomy while recognizing that language learning and the functioning of learner characteristics in second language (L2) learning can only be understood within specific sociocultural contexts (Lantolf \& Thorne, 2006). Despite this reorientation of language teaching, language teaching methodology courses still tend to focus almost entirely on teacher behaviors (Grosse, 1991a, 1993; Shrum \& Glisan, 2005). In an attempt to broaden the focus of

\footnotetext{
* Lama Nassif. Tel.: +1-413-597-2661

E-mail address: lama.nassif@williams.edu

http://dx.doi.org/...
} 
methodology classes, Horwitz, Breslau, Dryden, Yu, and McClendon (1997) and Horwitz, Hsieh, Bonzo, Huang, Na, and Rubrecht (2004) reported on a graduate-level language teaching methods course "designed to help teachers understand the foreign language (FL) classroom from the learner's perspective in order to prepare them better to foster learner autonomy through student-collaboration in their own classrooms" (Horwitz et al., 1997, p. 518). The course has five objectives to help language learners develop more positive learning characteristics within a learnerempowered environment (Griffiths, 2008):

The student will become familiar with recent literature and instructional approaches related to the following:

1. The relationship of individual factors to L2 achievement,

2. The experience of L2 learning,

3. Matching instruction to individual learner needs and characteristics,

4. Helping students become more effective language learners,

5. Supporting language learner autonomy.

The learner training assignment asks students to describe their learner population and give a rationale for their proposed training program. Using their experience with the target group, they are asked to address the following questions: What characteristics most impede your learners from learning your target language more effectively? What can you do to help your learners develop in those areas? The learner training project should describe the procedures the teacher will use to develop these characteristics and include the actual materials that the course participants would use with their students. The projects may take the form of websites, podcasts, lesson plans that would be implemented throughout a course, or any approach/medium that the teachers feel would be appropriate for their learner populations. Over the years, course participants have used a variety of formats including orientation pamphlets, pre-course workshops, podcasts, websites, study abroad orientations, and most recently, YouTube videos.

This paper describes three learner training projects for post-secondary learners resulting from the course. The project descriptions begin with a brief rationale, followed by a project overview and two sample activities. Two of the projects address English learning in foreign language contexts (Syria and Turkey), and the third focuses on Spanish learning in the US. (The Turkish and US projects were later implemented in the developers' classes.) None of the student groups are majors (specialists) in the language they are studying. The student populations for the Turkish and U.S. projects are undergraduates, and the Syrians are graduate students (Table 1).

Table 1. Overview of the projects

\begin{tabular}{lll}
\hline Project & Student population & Purpose \\
\hline 1 & Master's level non-English majors in Syria & Influence beliefs and expectations \\
\hline
\end{tabular}




\begin{tabular}{lll}
\hline 2 & Undergraduate non-English majors in Turkey & Reduce anxiety \\
\hline 3 & $\begin{array}{l}\text { Undergraduate students taking introductory-level Spanish as a } \\
\text { language requirement in the US. }\end{array}$ & $\begin{array}{l}\text { Encourage motivation and } \\
\text { autonomy }\end{array}$ \\
\hline
\end{tabular}

Within the language teaching literature, the term learner training has generally referred to the incorporation of components in language classes to help language learners approach L2 learning more effectively. Although it would seem that learner training could address a myriad of individual characteristics that would support more successful language learning, the literature has largely addressed strategy training (Rubin, 1987; Wenden, 1987a) and focused on approaches-called "strategy awareness raising," "strategy instruction," or "strategy-based instruction"-to help learners become aware of and adopt more appropriate language learning strategies (see, e.g., Chamot, 2005; Cohen, 2011; Oxford, 2011; Rubin, 1987; Wenden, 1987a). Learner training focusing on other characteristics that might help learners become more autonomous has not garnered as much interest (Oxford, 2015; Rees-Miller, 1993; Wenden, 1995). This point may simply be one of semantics, as the literature on other learner characteristics such as anxiety and motivation includes many suggestions for teachers to incorporate instructional approaches that help students control their anxiety or increase their motivation (see, e.g., Dörnyei, 1994; Gregersen, 2003; Young, 1999). In addition, a number of papers have addressed the issue of preparing students to become more autonomous learners (Cotterall, 2000; Little, 2007). The course described in this paper, and consequently the learner training projects reported here, address several learner characteristics including anxiety, motivation, and realistic expectations for language learning (beliefs). While the first two projects have specific variables of focus, the third project supports a wider variety of learner characteristics given the greater heterogeneity of language learning goals and prior target language contact in that student population.

\section{Project 1: Supporting realistic language learning beliefs in Syrian postgraduate English students}

\subsection{Target student population}

This project is directed at master's students enrolled in a six-month English course at a language institute at a large public university in Syria. $\dagger$ In Syria, English is primarily taught as a foreign language (EFL). The course meets for 10 hours a week and combines skill-based and content-based approaches to English for academic purposes including English for the social sciences, science and technology, and medical sciences. The students tend to be highly motivated, as English typically lies at the heart of their academic and professional goals and, most importantly, passing the course is a university requirement for completing graduate studies.

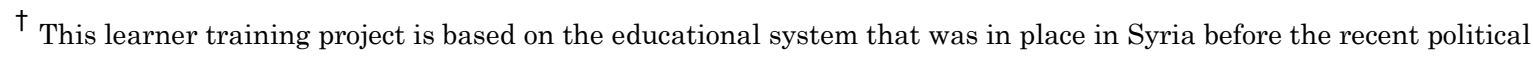
circumstances.
} 


\subsection{Rationale}

Many English classes at the pre-university level in Syria focus on reading and writing, and new students are generally not prepared for the communicative approaches they encounter at the institute. Accordingly, institute instructors and their incoming students tend to have different ideas about the process of language learning and appropriate practices for language learning and teaching. When students find that the language learning approaches they used in the past are not leading to success in their institute classes, they often become anxious and even doubt their abilities to learn English, adding to the stress they already feel about passing the course to be allowed to continue their studies.

Hosenfeld (1978) used the term "mini-theories" to describe students' preconceived ideas about language learning stemming from their cultural backgrounds and previous language learning experiences. Learner beliefs have been found to influence satisfaction with language classes (Dörnyei, 2005; Horwitz, 1987, 1988; Riley, 1997; Sykes, 2011), motivation (Dörnyei, 2005), and achievement (Abraham \& Vann, 1987; Cotterall, 1999; Ehrman \& Oxford, 1995), and consequently, many scholars have argued that teachers should promote more realistic beliefs (Benson \& Lor, 1999; Cotterall, 1999; Ellis, 2008; Horwitz 1987, 1988; Rashidi \& Omid, 2011; Sykes, 2011). Suggestions for helping learners develop more realistic beliefs about language learning include group discussions (Benson \& Lor, 1999) and providing knowledge about second language acquisition (SLA) research (Yang, 1999).

The project described here aims to orient students to their teachers' communicative expectations, encourage reflection on previous learning experiences, reduce anxieties associated with unrealistic beliefs, reconcile differences between teacher and learner beliefs, and generally promote more realistic beliefs about language learning. It addresses common language learning beliefs in Syria as well as some unproductive beliefs that have been reported in other contexts.

\subsection{Project structure}

This project is composed of three 90-minute workshops focusing on: (1) the difficulty of language learning, (2) the nature of language learning, and (3) learning and communication strategies (Horwitz, 1988). The workshops are offered during regular class sessions and begin early in the course (weeks 3,4 , and 5) in the hope that useful conversations about language learning would begin as soon as possible.

Each workshop follows a similar pattern: (1) warm up, (2) pair and small-group discussions, (3) whole-class discussions, (4) teacher presentation, and (5) final wholeclass discussion. The students share information about their learning experiences and receive reassurances about their learning difficulties and concerns. Following the small-group and whole-class discussions, the teacher gives a brief presentation of relevant information from the SLA literature. Since Syrian students tend to accept teacher expertise, teacher presentations offer information in a form to which they will 
likely be receptive. At the end of the workshops, the students will discuss their experiences and their plans for approaching English during the institute course and in the future.

\subsection{Sample activity 1: How much should I worry about making errors?}

This odd-one-out activity (Figure 1.1) during the first workshop initiates small group and whole-class discussions about the natural occurrence of errors and their importance as signs of language learning. Figure 1.2 outlines the activity procedures, and Figure 1.3 presents sample PowerPoint slides from the teacher presentation.

\section{Workshop 1}

\section{Activity 1: Group discussion 2: How much should I worry about making} errors when speaking or writing in English?

Discuss the following in groups of three. You may use Arabic when needed. Be prepared to share your ideas with the class.

Of the three opinions below, which is "the odd one out"? How is it different from the other two? What does it mean to you?

- You shouldn't say anything in English until you say it correctly.

- It is important to speak and write in English even if I make errors.

- It is important for the teacher to correct every error I make

Figure 1.1. Sample activity 1: How much should I worry about making errors when speaking or writing in English?

Similar to other activities in the three workshops, this activity employs collaboration and discussion. The examples from the SLA literature, accompanied by the class discussion, explicitly address errors, interlanguage, and language output.

\begin{tabular}{|c|c|}
\hline Duration & Activity procedures \\
\hline 10 minutes & $\begin{array}{l}\text { - In groups of three, have the students discuss which of the } \\
\text { beliefs is the "odd one out." } \\
\text { - Have students discuss each belief statement and how the "odd } \\
\text { one out" differs from the others. } \\
\text { - Ask students to relate some of their language learning } \\
\text { experiences that reflect their beliefs about making mistakes. }\end{array}$ \\
\hline 10 minutes & $\begin{array}{l}\text { - As a class, discuss students answers. Ask them to justify } \\
\text { their choices. } \\
\text { - Ask students to share examples from their group discussions } \\
\text { that reflect their beliefs about making mistakes. }\end{array}$ \\
\hline 20 minutes & - Refer the students to the quotations in the teacher \\
\hline
\end{tabular}


presentation (PowerPoint slides 1-4. (Figure 1.3)

- Ask students to explain what they understood from each quotation. Initiate a discussion of what the quotation means to them as language learners and how they could apply it to their own learning.

Figure 1.2. Sample activity 1 procedures

\section{THOUGHTS FROM SECOND LANGUAGE ACQUISITION}

\begin{abstract}
- A learner's errors "provide evidence of the language system he is using (i.e., has learned) at a particular point in the course (and it must be repeated that he is using some system, although it is not yet the right system) ${ }^{n}$ (Corder, 1967, p. 167)
o Errors are signs of learning rather than indicators of imperfection.

- Practice makes perfect!
\end{abstract}

\section{THOUGHTS FROM SECOND LANGUAGE ACQUISITION}

- Learner language is a distinct system: Interlanguage Selinker (1972)

- "The interlanguage is viewed as a separate linguistic system, clearly different from both the learner's 'native language' (NL) and the 'target language' (TL) being learned, but linked to both NL and TL by interlingual identifications in the perception of the learner" (Tarone, 2006, p. 747).

\section{THOUGHTS FROM SECOND LANGUAGE ACQUISITION} $\circ$ Errors:

- "tell the teacher how far towards the goal the learner has progressed and consequently, what remains for him to learn."

- "They provide to the researcher evidence of how language is learned or acquired, what strategies or procedures the learner is employing in his discovery of the language."

- most importantly, "are indispensable to the learner himself, because we can regard the making of errors as a device the learner uses in order to learn" (Corder, 1967, p. 167)

\section{THOUGHTS FROM SECOND LANGUAGE ACQUISITION}

o So, speak and write even if you make errors!

-Why is it important to speak and write?

- Output "pushes learners to process language more deeply (with more mental effort) than does input" (Swain, 1995, p. 126).

- Output promotes "an analysis of incoming data, that is, a syntactic analysis of input" (Swain \& Lapkin, 1995, p $375)$, and, as a result, syntactic accuracy.

Figure 1.3. Sample activity 1 PowerPoint slides

\subsection{Sample activity 2: What does it mean to know a second language?}

This activity (Figure 1.4) initiates discussions on the nature of language learning. It aims to challenge any misconceptions the students hold about language learning and language competence. The activity requires the learners to rank a list of language components in order of importance. The activity aims to reinforce the idea that all language components are intertwined and must be learned in coordination to advance L2 competence. Understanding the components may also help students assess their language competence more realistically, with the possibility of boosting their motivation and self-confidence. A discussion of the nature of communicative competence might also help students better understand the rationale for the 
communicative activities they encounter in their English classes. Figure 1.5 outlines this activity, and Figure 1.6 presents sample PowerPoint slides from the teacher presentation.

\section{Workshop 2}

\section{Activity 2: Group discussion 2: What does learning a language?}

Discuss the following in groups of three. You may use Arabic when needed. Be prepared to share your ideas with the class.

Add three aspects of the language learning to the list below. Arrange the statements in order of importance.

The most important part of learning English is

- learning vocabulary words;

- learning the grammar;

- learning how to maintain successful communication;

- learning about English-speaking cultures;

$\bullet$

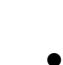

Figure 1.4. Sample activity 2 : What does learning a language involve?

\begin{tabular}{|c|c|}
\hline Duration & Activity procedures \\
\hline 15 minutes & $\begin{array}{l}\text { - Divide the class into new groups of three. } \\
\text { - Have the groups discuss the statements, add two statements of } \\
\text { their own about what it means to know a language, and arrange the } \\
\text { statements in order of importance. } \\
\text { - Ask students to justify their decisions and to support their additions } \\
\text { and arrangements of the statements. } \\
\text { - Give students poster paper for their reordered statements and any } \\
\text { additions. Post the lists on classroom walls. } \\
\text { - Have the students walk around the classroom to read their } \\
\text { classmates' posters. }\end{array}$ \\
\hline 15 minutes & $\begin{array}{l}\text { - Point out several posters, raising questions about the rationale } \\
\text { behind the belief arrangements and the choice of additional } \\
\text { language components. } \\
\text { - Have students give their reasons and respond to each other's } \\
\text { arguments. } \\
\text { - Ask students to share examples to support their choices. } \\
\text { - Use the students' arguments to start a discussion about (1) what it } \\
\text { means to know another language, (2) the nature of communicative } \\
\text { competence in an L2, and (3) the idea that no aspect of language } \\
\text { competence is superior to others and the components of language }\end{array}$ \\
\hline
\end{tabular}




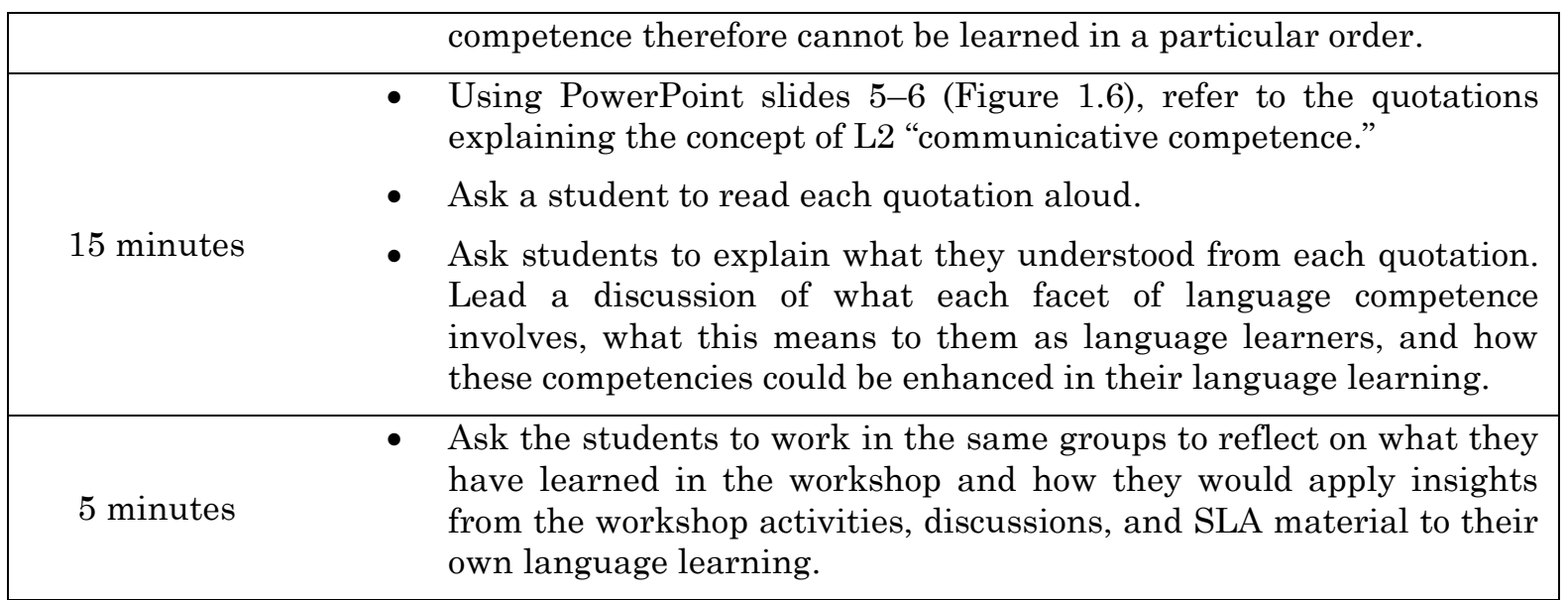

Figure 1.5. Sample activity 2 procedures

Communicative Competence: (CAnale, 1983)

- Grammatical competence

- Knowledge of the "language code;" knowledge of "vocabulary, word formation, sentence formation, pronunciation, spelling and linguistic semantics"

Discourse competence

- "Mastery of how to combine grammatical forms and meanings to achieve a unified spoken or written text in different genres" (p.9)
Communicative Competence: (CAnale, 1983)

- Sociolinguistic competence

- "The extent to which utterances are produced and understood appropriately in different sociolinguistic contexts depending on contextual factors" (p. 7)

- Strategic competence

- "Verbal and non-verbal communication strategies [used to] compensate for breakdowns in communication [and] enhance the effectiveness of communication" (pp. 10-11)

Figure 1.6. Sample activity 2 PowerPoint slides

\section{Project 2: Reducing Turkish college-level English learners' foreign language anxiety}

\subsection{Target student population}

This learner project is directed at undergraduate non-English majors attending a public university in Turkey. They are enrolled in an intensive English program designed to prepare them to pass the required college-entrance English proficiency test at the university. It is common in Turkey for both public and private universities to require incoming freshmen to pass an English examination.

English is the most commonly taught foreign language in Turkey, and as was the case in Syria, English is taught as a foreign language and proficiency in English is associated with better employment opportunities and higher incomes. Following 12 years of formal English instruction, students come to university with varying levels of English proficiency. Their limited previous exposure to English-usually only four hours per week with a heavy focus on grammar and memorization-contributes to 
their anxiety. Their probationary status in the English course is also an important source of anxiety.

\subsection{Rationale}

Reducing foreign language anxiety (FLA) is necessary for these learners for several important reasons. First, English is the medium of instruction in some public and many private universities in Turkey, and English competence is necessary for advanced study and professional purposes. Failure to attain sufficient oral ability in English is an impediment to most academic and professional goals. Second, since the students have had only limited exposure to English prior to college, they are not wellprepared for college English classes. The fact that these students are in a remedial English program contributes to their anxiety as well. Finally, in intensive English programs in Turkey, learners are expected to demonstrate high oral and aural skills on production-focused exit exams, which themselves are highly anxiety provoking (Kim, 2000; Oxford, 1990; Young, 1990).

FLA has been found to have a substantial negative impact on language learning. Students who experience anxiety about language learning are more likely to do poorly in language study (Horwitz, 2008), drop out of language programs (Dewaele \& Thirtle, 2009), and be less willing to communicate in their second language (Lui \& Jackson, 2008; MacIntyre, 2007). Importantly, anxiety has been found to affect other important language learning characteristics including motivation (Yan \& Horwitz, 2008), perceived competence (Kitano, 2001), beliefs (Yan \& Horwitz, 2008), and strategy use (Gregersen \& Horwitz, 2002). While it is generally believed that language anxiety cannot be entirely eliminated, it may be reduced by identifying group- or individualspecific, anxiety-provoking elements and/or incorporating anxiety-reduction activities into language curricula (Horwitz, 2013; Lui \& Jackson, 2008; Oxford, 1990; Young, 1990).

\subsection{Project structure}

This project includes four 50-minute workshops implemented during the first four weeks of the course. To personalize the workshops, an electronic group blog was first established to elicit students' thoughts and experiences with FLA. Forty-one students posted on the blog, and their perceptions of FLA showed that they held several beliefs about language learning that likely contributed to their anxieties. For instance, they wrote about feeling the need to understand every English sentence before participating in class activities and about not knowing enough vocabulary words to speak in English. Students also wrote about their fear of making mistakes in speaking and pronunciation as well as their fear of being laughed at by classmates.

The activities in the anxiety-reduction workshops addressed the specific antecedents of anxiety identified in the students' blog postings. Thus, the workshops were designed to decrease FLA by (1) helping the students develop more realistic beliefs about language learning, (2) introducing useful language learning strategies, 
and (3) helping them reflect on how unrealistic beliefs, lack of strategy awareness, and limited visions of successful language learners (e.g., a successful language learner must be intelligent) can lead to anxiety. Given these varied sources of anxiety, it was decided that anxiety-reduction strategies would be introduced early in the program, and since students tend to feel more confident when working with partners or in small groups (Horwitz, 2001; Yan \& Horwitz, 2008; Young, 1991), each session included a partner or small-group activity.

\subsection{Sample activity 1: How realistic are our beliefs?}

Lack of vocabulary, worry over mistakes, and dissatisfaction with their proficiency were the major reasons students were uncomfortable participating in English class activities. The purpose of this activity (Figure 2.1), therefore, is to identify "(un)healthy" beliefs and increase awareness of the realities of language learning. Figure 2.2 outlines the activity procedures, and Figure 2.3 presents a sample slide from the teacher presentation.

\section{Workshop 2}

\section{Activity 1: Group discussion: How realistic are our beliefs?}

You have 10 minutes to discuss the following statements in groups of four. Please decide the extent to which your group agrees with the following statements and be prepared to share your ideas with the class.

1. It is important to speak English with excellent pronunciation.

2. You shouldn't say anything in English until you say it correctly.

3. The most important part of learning a foreign language is learning vocabulary.

4. If someone spent an hour a day learning a language, how long would it take them to learn that language very well?

- less than a year

- 1-2 years

- 3-5 years

- 5-10 years

- You can't learn a language in one hour a day

Figure 2.1. Sample activity 1: How realistic are our beliefs?

\begin{tabular}{|lll|}
\hline Duration & \multicolumn{1}{c|}{ Activity procedures } \\
\hline \multirow{2}{*}{10 minutes } & $\bullet$ & Divide the class into groups of four. \\
& $\bullet$ & Students read the activity instructions and discuss which of the \\
\hline
\end{tabular}




\begin{tabular}{|lll|}
\hline & beliefs they agree/disagree with. \\
& - & Ask the students to justify their answers. \\
& - & Ask them to give examples to support their choices. \\
\hline \multirow{2}{*}{10 minutes } & $\bullet$ & Each group chooses a leader to share their group's ideas with the \\
& larger group. \\
\hline 10 minutes & - & Each group has $2-3$ minutes to present their ideas. \\
\hline
\end{tabular}

Figure 2.2. Sample activity 1 procedures

1. Some ways to improve your vocabulary repertoire:

- Using word families

- Guessing vocabulary through contextual clues

- Using a vocabulary log

- Using a dictionary

- Doing extensive reading

2. Making mistakes is part of the learning process.

3. Language learning takes time.

Figure 2.3. Sample activity 1 PowerPoint slide

\subsection{Sample activity 2: Identifying anxiety sources and reflecting on personal language learning experiences}

This activity (Figure 2.4) is designed to help learners analyze potential anxietyprovoking situations and provide suggestions to lessen the anxiety. This task helps learners understand that the factors that make them feel anxious are not unique to them and that anxiety can be reduced through increased awareness of anxietyprovoking beliefs and the use of more productive language learning strategies. Figure 2.5 outlines the activity procedures, and Figure 2.6 presents a sample slide from the teacher presentation.

Workshop 3
Activity 2: What would you advise?
These students are asking for advice about learning English. Considering what we
have discussed so far, what would you advise them to do? Do you think they have any
unrealistic beliefs about learning English? (Feel free to use Turkish when needed.)
Each group should choose one case to discuss. What would you advise the person to
do? Be prepared to share your suggestions with the rest of the class.
- Melisa is an 18-year-old student studying English at a preparatory school
in Turkey. She is very shy and rarely participates in her English class. She


wants to speak English very well but is afraid to speak because she is worried about making mistakes when speaking. What should she do? What would you say to her?

- Ali is a 22-year-old student who wants to speak English fluently and communicate with international students. He always gets high scores on grammar and reading exams, but he does not participate in the discussions in his English class. Ali thinks his vocabulary is too limited to express himself accurately in class. What should he do? What would you say to him?

- Deniz is a 20-year-old student who is very motivated to learn English because it is important for her career plans. She needs to communicate very well in English to study American literature. However, whenever she is asked to speak in class, she starts sweating and trembling. She also says she is afraid of being ridiculed by her classmates. What should she do? What would you say to her?

Figure 2.4. Sample activity 2: What would you advise?

\begin{tabular}{|lll|}
\hline Duration & \multicolumn{1}{c|}{ Activity procedures } \\
\hline \multirow{2}{*}{15 minutes } & - & Divide the class into groups of four. \\
& - Students read the activity instructions and choose one situation. \\
& - Students discuss the advice they would consider giving. \\
\hline 10 minutes & - & The groups should take each case and discuss possible ways to help \\
& & each learner. \\
\hline
\end{tabular}

Figure 2.5. Sample activity 2 procedures

Melisa: Making mistakes is natural in language learning. Making mistakes means you are learning.

Ali: Even with limited vocabulary, learners can communicate. Once learners start using the language, they will naturally enlarge their vocabulary storage. In addition, there are several strategies that learners can use to widen their vocabulary depth.

Deniz: Language classrooms are labs where learners test drive their knowledge. Learners are expected to make mistakes, and the ones who make mistakes are usually the ones who take risks and learn faster and better. Thus, learners should take risks and participate as much as possible.

Murat: It is important to keep in mind that language learning takes time and requires consistent effort and devotion. Also, learners should not expect to know every word to understand the main idea of a text or conversation. Utilizing several language learning strategies will equip you with the resources to successfully understand the main ideas in a text or in a conversation. 


\section{Project 3: Supporting American undergraduate students' learning of Spanish as a foreign language}

\subsection{Target student population}

This learner training project targets undergraduate students enrolled in a firstsemester Spanish class at a large public university in the United States. This firstsemester course is part of a required foreign language sequence for most of the students. In contrast to the first two learner populations described in this paper, these learners' language learning goals are more diverse. Some of these learners view Spanish proficiency as economically and socially advantageous (Kubota \& Catlett, 2008; Watzke, 2003), especially in light of the growing Spanish-speaking population in Texas in the US. At the same time, some students are integratively motivated and want to get to know and communicate with family members or with the growing Spanish speaking community in the southwestern United States.

Furthermore, the learner population includes both heritage and non-heritage learners in a 15-week course. Although many undergraduates in Texas have previously encountered Spanish through informal language contact (Toribio, 2004), Spanish instruction (Blake \& Zyzik, 2003), or dual-language programs (Ray, 2009), the majority of students in this course are not likely to have experienced extended or consistent Spanish instruction or contact with Spanish speakers.

\subsection{Rationale}

This student population is more diverse in terms of motivation, proficiency, and opportunities to use their developing language skills than those described in the first two projects. Although some of these students may have personal goals for learning Spanish, many of them are simply taking the course as a graduation requirement. In addition, Spanish must be taught both as a foreign and as a second language. Some students want to use Spanish for work within the US, while others imagine using the language in Spain or Latin America. Thus, it is especially difficult to identify a single focus for this learner training project. Instructors for the first-semester course make strong cases for their students' need for a number of characteristics including motivation, flexible learning strategies, and willingness to communicate. The website format allowed for greater individualization than was afforded by the more teachercentered approaches designed for the English learners in Syria and Turkey. Motivation and learner autonomy are the core of this project, since it was designed to encourage learners to assume control over their language learning and provide them with the tools to do so in real life and online contexts. As noted earlier, motivation is associated with learner beliefs and anxiety (Dörnyei, 2005; Yan \& Horwitz, 2008), and effective strategy use has been found to support motivation (Oxford, 2011). Motivation and learner autonomy are also intimately related (Noels, 2001; Ryan \& Deci, 2000; Ushioda, 2001; Wu, 2003), and motivation is an important factor in learners' willingness to communicate (MacIntyre, Clement, Dörnyei, \& Noels, 1998). 
Willingness to communicate is fundamental to learner autonomy particularly in the Texas context where there are often opportunities to communicate with Spanish speakers.

\subsection{Project structure}

This project uses a teacher-created, four-section website that coordinates with the first four class sessions: "Your Experience with Languages," "Your Thoughts on Foreign Language Learning," "Real Strategies You Can Use for Success," and "What to Expect This Semester" (Figure 3.1). The first in-class session includes an activity to help learners get to know each other and become familiar with the website. In preparation for the second class session, students complete two short surveys about their motivations, beliefs about Spanish knowledge, and existing Spanish knowledge. For example, learners are asked to indicate their main reason for taking the course: (1) To make me more competitive in whatever job I have in the future; (2) Because I want to socialize with Spanish speakers; (3) Because my degree plan forces me to take a language (ugh!), and it might as well be Spanish because we're in Texas; and (4) Because the other language class (French, Mandarin, Arabic, etc.) I wanted to take for my degree plan didn't work with my schedule. $\$$ Next there is a question on their beliefs about the importance of accuracy and fluency in language learning (i.e., "I don't want to use my Spanish unless it's perfect" or "I just want to get my point across"). They are also asked to consider how much Spanish they already know. Responses to these questions are the focus of small-group discussions during Class Session 2. Under "Real Strategies You Can Use for Success," learners see a list of strategies categorized by language skill and context (Class Session 3). By Session 4, students have completed the preparatory activities on the website, and this final session focuses on any questions they may have about the class procedures listed on the site.

\footnotetext{
‡ The teacher used a casual writing style in the website to support more open communication with the students.
} 


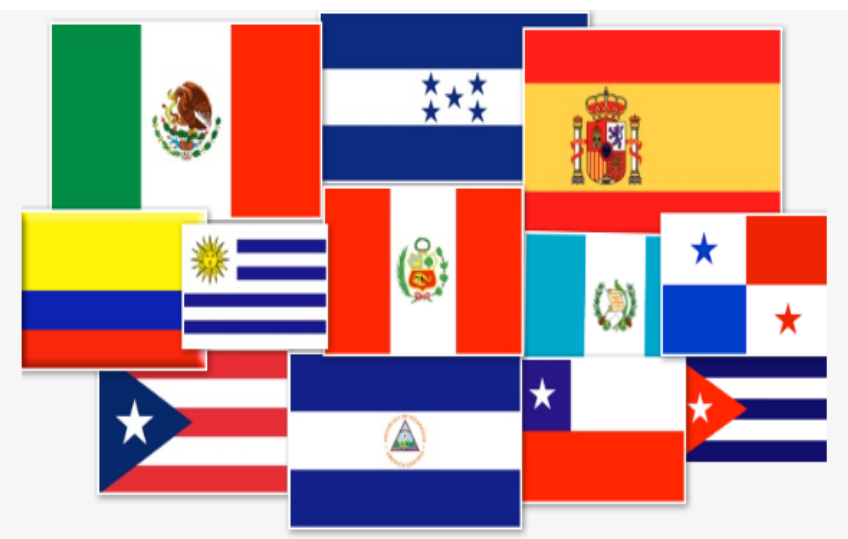

\section{Spanish 601D: Welcome to our site!}

This introduction takes less than 10 minutes and has two goals:

1) to help you be a more effective language learner and

2) to give me, your professor, an idea of how I can help

Google's Chrome browser does not support this website. Please use with Mozilla Firefox, Apple's Safari, or Windows Explore.

Begin here:

Part 1: Your experience with foreign languages

Part 2: Your thoughts on foreign language learning

Part 3: Real strategies you can use for success

Part 4: What to expect this semester

Please keep in mind that your responses cre entrey anonymous

Please do not indicate your name anywhere on this webste.

Please feel froe to emaime.

Figure 3.1. Website home page

\subsection{Sample activity: Part 3: Familiarizing learners with language learning strategies}

Part 3 of the website introduces a number of language learning strategies (Figure 3.2). Under the link "How do I study Spanish," the strategies are divided by skill and context. Learners are asked to select the skill/context that they are most concerned about: speaking face to face; speaking, listening, writing, and intercultural communication online; reading for class; reading for fun; writing; listening with video; listening without video; grammar and vocabulary; and studying for exams. Each skill/context combination is hyperlinked for clarity of presentation. Figure 3.3 outlines the activity procedures, and Figure 3.4 lists websites students can use for practice outside of class. 


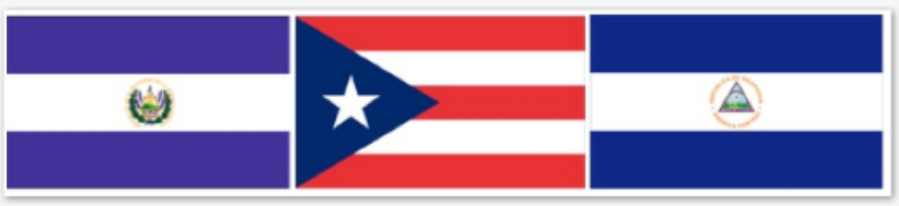

Part 3: Real strategies you can use for success

Feel tree to emall me about part 3.

Click on any link to open:

How do I study Spanish?

Useful websites for learning Spanish

Stop and think about what you already know

Basic parts of speech

Word order

Comprehension strategies

or

Skip to Part 4 about our class

$\ll<$ Go back home

Figure 3.2. Part 3: Strategies for success

\begin{tabular}{|ll|}
\hline Duration & \multicolumn{1}{c|}{ Activity procedures } \\
\hline & $\begin{array}{l}\text { For homework, learners are directed to the link "How do I } \\
\text { study Spanish?" under Part 3: Real strategies you can use for } \\
\text { success. }\end{array}$ \\
- & $\begin{array}{l}\text { Learners select any strategy from this page, read about the } \\
\text { strategies suggested by the instructor, and compose a short } \\
\text { paragraph in English about why they chose that particular } \\
\text { skill/context, how they will employ it this semester, and any } \\
\text { other ideas they might have. }\end{array}$ \\
\hline 10 minutes & $\begin{array}{l}\text { During Class 3, learners work in small groups according to } \\
\text { the skill/context they chose in order to present a brief } \\
\text { summary of the strategies discussed with their classmates. } \\
\text { The instructor clarifies any learner misunderstandings and } \\
\text { comments on effective strategy use. }\end{array}$ \\
\hline
\end{tabular}

Figure 3.3. Sample activity procedures 


\section{Speaking, listening, writing, and intercultural communication online}

Livemocha, Busuu, and italki are social networking sites like Facebook (you can even log in through your FB account) that connect language learners in real time over the Interwebs. You can set up a free account and immediately find native Spanish speakers online who are also trying to learn a language-English! Hey, you know that one already! :) So you can instant message, voice chat, or video chat with a Spanish speaker, half of the time in English and half of the time in Spanish. It's called tandem learning, and it's a great way to find Spanish speakers if you don't have many in your neighborhood or if you're too nervous to use Spanish in real life. These sites also have structured Spanish language learning content if you want to "take a class," and there are other social networking features such as media sharing and online friends.

Figure 3.4. Strategies for speaking, listening, writing, and intercultural communication online

\section{Conclusions}

The learner training projects described here were representative of the projects completed in the second language learner course over the years. Many students select a workshop approach similar to the ones described here in the Syrian and Turkish EFL contexts. Websites including general information about language learning and/or about the particular language course, like the one associated with the beginning Spanish course, are also commonly used. The class blog used to elicit students' personal experiences with FLA in the Turkish context was a particularly inventive approach that allowed the teacher to include the students' concerns in the learner training activities.

The projects described in this paper were also typical of the kinds of student characteristics that course participants have chosen to address over the years, with strategies, learner beliefs, and anxiety being the most frequent project foci B But it is also true that in each case, the individual characteristics addressed in these learner training projects lead the project developer to focus on additional characteristics. This is logical since human traits necessarily interact with each other and do not exist in isolation. It is difficult, for example, to imagine that a completely unmotivated student would experience language learning anxiety. In the projects described here, anxiety and learner beliefs were seen as particularly related.

The issues of how much time to allocate to learner training and whether the training should take place in the target language or the students' language are important ones. Workshops and websites are seen as time efficient and able to accommodate either language. The projects described here are meant to be implemented at the beginning of language courses rather than more systematically 
throughout a semester/course, at the same time, learner training issues are expected to come up informally from time to time.

Finally, with the exception of the class blog in the Turkish context, the projects included here tended to be teacher centered in both conception and mode of presentation. The teachers chose the student characteristics to concentrate on and the activities to develop those characteristics. Since most of the course participants were not teaching while they were taking the second language learner class, it was not possible for them to include students in determining the parameters of their projects. In addition, especially in the Syrian and Turkish EFL contexts, the students would expect language instruction to be teacher centered. Even so, the lack of student input is a major concern because the goal of the second language learner course is to help language teachers become more learner centered and especially because learners themselves are the best authorities on what they need. For that reason, it is important to identify ways to recognize and incorporate learners' perceptions of their needs.

\section{Implications and Recommendations}

The developers of this group of learner training projects were members of the same cultural group as the targeted students, and the projects were designed within the educational systems of the three groups. The general question of native and nonnative language teachers is a complicated one, and the literature on the topic cannot be summarized here, but the experiences of the instructor and participants in this course cause us to wonder specifically about the role of culture in learner training. Do some cultures tend to emphasize particular learner characteristics or modes of implementation? Is the concept of learner training more compatible with certain educational cultures than with others? What issues arise when teachers and students are members of different cultural groups? Clearly, from a sociocultural perspective, learner training needs to take the specific culture and learning context into account.

The question also arises as to whether language learner training should only address student characteristics. The course instructor conceptualized the projects as a means to develop individual learner factors, but her expectations were challenged one semester when a student offered an unusual project for adult ESL learners: The student prepared a Spanish-language pamphlet listing free and low-cost English classes in their city, supplemented with bus schedules and child-care options. She argued that life circumstances including finances were the primary obstacles to language learning for these students. Moreover, although free and low-cost English classes were fairly readily available, many eligible students were simply unaware of the classes. Consequently, in addition to preparing the pamphlets, the student convinced a local chain of grocery stores to reproduce and distribute her pamphlets at the checkout lines in their stores with substantial numbers of Spanish-speaking customers. Ultimately, since this student's project made it possible for her group of adult English learners to be more successful, the instructor had to agree that the 
student had fulfilled the assignment. The pamphlets could also be seen as facilitating "planning," a metacognitive strategy in Oxford's (1990) taxonomy.

This student's unconventional learner training project also brought about a broader question about the term learner training. Rubin, Chamot, Harris, \& Anderson (2007) use the term strategy-based instruction for teaching approaches similar to what we called learner training in this paper. Nonetheless, we feel that the term strategybased instruction is still too limited. We suggest that the term learner support is a better way to conceptualize the implementation of learner development into language curricula. In order to address a broad range of learner characteristics in second and foreign language instruction as well as include necessary learning resources, language educators should strive to support learners in all ways possible.

\section{References}

Abraham, R., \& Vann, R. (1987). Strategies of two language learners: A case study. In A. Wenden \& J. Rubin (Eds.), Learner strategies in language learning (pp. 85-102). Englewood Cliffs, NJ: Prentice Hall.

Amuzie, G. L., \& Winke, P. (2009). Changes in language learning beliefs as a result of study abroad. System, 37(3), 366-379.

Benson, P., \& Lor, W. (1999). Conceptions of language and language learning. System, 27(4), $459-472$.

Blake, R. J., \& Zyzik, E. C. (2003). Who's helping whom? Learner/heritage-speakers' networked discussions in Spanish. Applied Linguistics, 24, 519-544.

Chamot, A. U. (2005). Language learning strategy instruction: Current issues and research. Annual Review of Applied Linguistics, 25, 112-130.

Cohen, A. D. (2011). Strategies in learning and using a second language (2nd ed.). Harlow, England: Pearson Education.

Cotterall, S. (1999). Key variables in language learning: What do learners believe about them? System, 27(4), 473-492.

Cotterall, S. (2000). Promoting learner autonomy through the curriculum: Principles for designing language courses. ELT Journal, 54(2), 109-117.

Dewaele, J., \& Thirtle, H. (2009). Why do some young learners drop foreign languages? A focus on learner-internal variables. International Journal of Bilingual Education and Bilingualism, 12(6), 635-649.

Dörnyei, Z. (1994). Motivation and motivating in the foreign language classroom. The Modern Language Journal, 78(3), 273-284.

Dörnyei, Z. (2005). The psychology of the language learner: Individual differences in second language acquisition. Mahwah, NJ: Lawrence Erlbaum Associates.

Ehrman, M. E., \& Oxford, R. L. (1995). Cognition plus: Correlates of language learning success. The Modern Language Journal, 79(1), 67-89.

Ellis, R. (2008). Learner beliefs and language learning. The Asian EFL Journal Quarterly, $10(4), 7-25$.

Gregersen, T. (2003). To err is human: A reminder to teachers of language-anxious students. Foreign Language Annals, 36(1), 25-32. 
Gregersen, T., \& Horwitz, E. K. (2002). Language learning and perfectionism: Anxious and non-anxious language learners' reactions to their own oral performance. The Modern Language Journal, 86(4), 562-570.

Griffiths, C. (2008). Lessons from good language learners. Cambridge, UK: Cambridge University Press.

Grosse, C. U. (1991a). The TESOL methods course. TESOL Quarterly, 25(1), 29-49.

Grosse, C. U. (1993). The foreign language methods course. The Modern Language Journal, 77(3), 303-312.

Horwitz, E. K. (1987). Surveying student beliefs about language learning. In A. Wenden \& J. Rubin (Eds.), Learner strategies in language learning (pp. 119-129). Englewood Cliffs, NJ: Prentice Hall.

Horwitz, E. K. (1988). The beliefs about language learning of beginning university foreign language students. The Modern Language Journal, 72(3), 283-294.

Horwitz, E.K. (2001). Language anxiety and achievement. Annual Review of Applied Linguistics, 21, 112-126.

Horwitz, E. K. (2013). Becoming a language teacher: A practical guide to second language learning and teaching ( $\left.2^{\text {nd }} \mathrm{ed}.\right)$. Boston: Pearson Education Inc.

Horwitz, E. K., Breslau, B., Dryden, M. A., Yu, J. F., \& McClendon, M. E. (1997). A graduate course focusing on the second language learner. The Modern Language Journal, 81(4), 518526.

Horwitz, E. K., Horwitz, M. B., \& Cope, J. (1986). Foreign language classroom anxiety. The Modern Language Journal, 70(2), 125-132.

Horwitz, E. K., Hsieh, P. H., Bonzo, J. D., Huang, D., Na, Y. H., \& Rubrecht, B. G. (2004). Case studies of language learners as a tool for helping teachers understand the experience of language learning. HongKong Journal of Applied Linguistics, 9, 1-14.

Hosenfeld, C. (1978). Students' mini-theories of second language learning. Association Bulletin, 29(2), 31-40.

Kitano, K. (2001). Anxiety in the college Japanese language classroom. The Modern Language Journal, 85(4), 549-566.

Kubota, R., \& Catlett, S. (2008). Spanish only for foreign language in the elementary school (FLES): Competing discourses in local language policy. Foreign Language Annals, 41(1), $102-118$.

Lantolf, J. P., \& Thorne, S. L. (2006). Sociocultural theory and the genesis of second language development. Oxford, England: Oxford University Press.

Little, D. (2007). Language learner autonomy: Some fundamental considerations revisited. International Journal of Innovation in Language Learning and Teaching, 1(1), 14-29.

Lui, M., \& Jackson, J. (2008). An exploration of Chinese EFL learners' unwillingness to communicate and foreign language anxiety. The Modern Language Journal, 92(1), 71-86.

MacIntyre, P. D. (2007). Willingness to communicate in the second language: Understanding the decision to speak as a volitional process. The Modern Language Journal, 91(4), 564576.

MacIntyre, P. D., Clement, R., Dörnyei, Z., \& Noels, K. A. (1998). Conceptualizing willingness to communicate in a L2: A situational model of L2 confidence and affiliation. The Modern Language Journal, 82(4), 545-562.

Noels, K. A. (2001). Learning Spanish as a second language: Learners' orientations and perceptions of their teachers' communication style. Language Learning, 51(1), 107-144.

Oxford, R. L. (1990). Language learning strategies: What every teacher should know. Boston, MA: Heinle \& Heinle. 
Oxford, R. (2011). Teaching and researching language learning strategies. Harlow, England: Pearson.

Oxford, R. L. (2015). Expanded perspectives on autonomous learners. Innovation in Language Learning and Teaching, 9(1), 58-71.

Rashidi, N., \& Omid, A. (2011). A survey on Iranian EFL learners' beliefs on the role of rote memorization in learning vocabulary and its effect on vocabulary achievement. Pan-Pacific Association of Applied Linguistics, 15(1), 139-161.

Ray, J. M. (2009). A template analysis of teacher agency at an academically successful dual language school. Journal of Advanced Academics, 21, 110-141.

Rees-Miller, J. (1993). A critical appraisal of learner training: Theoretical bases and teaching implications. TESOL Quarterly, 27(4), 679-689.

Riley, P. (1997). 'BATs and BALLs': Beliefs about talk and beliefs about language learning. Mélanges Pédagogiques, 23, 125-153.

Rubin, J. (1987). Learner strategies: theoretical assumptions, research history and typology. In A. Wenden \& J. Rubin (Eds.), Learner strategies in language learning (pp. 15-30). Englewood Cliffs, NJ: Prentice Hall.

Rubin, J., Chamot, A. U., Harris, V., \& Anderson, N. J. (2007). Intervening in the use of strategies. Language learner strategies, 30, 29-45.

Ryan, R. M., \& Deci, E. L. (2000). Intrinsic and extrinsic motivations: Classic definitions and new directions. Contemporary Educational Psychology, 25, 54-67.

Shrum, J., \& Glisan, E. (2005). Teacher's handbook: Contextualized language instruction (3rd ed.). Boston, MA: Heinle.

Sykes, J. (2011). Facilitating reflection on implicit learner beliefs through metaphor elicitation. Pan-Pacific Association of Applied Linguistics, 15(1), 91-113.

Tanaka, K., \& Ellis, R. (2003). Study abroad, language proficiency, and learner beliefs about language learning. JALT Journal, 25(1), 63-85.

Toribio, A. J. (2004). Spanish/English speech practices: Bringing chaos to order. International Journal of Bilingual Education and Bilingualism, 7, 133-154.

Ushioda, E. (2001). Learner autonomy in Irish L2 classrooms: New initiatives. In L. Karlsson, F. Kjisik, \& J. Nordlund (Eds.), All together now (pp. 219-225). Helsinki, Finland: University of Helsinki Press.

Watzke, J. L. (2003). Lasting change in foreign language education: A historical case for change in national policy. Westport, CT: Praeger.

Wenden, A. (1987a). Conceptual background and utility. In A. Wenden \& J. Rubin (Eds.), Learner strategies in language learning (pp. 3-13). Englewood Cliffs, NJ: Prentice Hall.

Wenden, A. L. (1995). Learner training in context: A knowledge-based approach. System, 23(2), 183-194.

White, C. (1999). Expectations and emergent beliefs of self-instructed language learners. System, 27(4), 443-457.

$\mathrm{Wu}, \mathrm{X}$. (2003). Intrinsic motivation and young language learners: The impact of the classroom environment. System, 31(4), 501-517.

Yan, J. X., \& Horwitz, E. K. (2008). Learners' perceptions of how anxiety interacts with personal and instructional factors to influence their achievement in English: A qualitative analysis of EFL learners in China. Language Learning, 58(1), 151-183.

Yang, N. (1999). The relationship between EFL learners' beliefs and learning strategy use. System, 27(4), 515-535. 
Young, D. J. (1990). An investigation of students' perspectives on anxiety and speaking. Foreign Language Annals, 23(6), 539-553.

Young, D. J. (1991). Creating a low-anxiety classroom environment: What does the anxiety research suggest? The Modern Language Journal, 75(4), 426-439.

Young, D. J. (1999). Affect in foreign language and second language learning: A practical guide to creating a low-anxiety classroom atmosphere. New York, NY: McGraw Hill.

\section{Copyrights}

Copyright for this article is retained by the author(s), with first publication rights granted to the Journal.

This is an open-access article distributed under the terms and conditions of the Creative Commons Attribution license (CC BY-NC-ND) (http://creativecommons.org/licenses/by-nc-nd/4.0/). 